\title{
Research on Applied Talent Training of China's Universities Based on Academic Competition
}

\author{
Haiyan Gao \\ Yulin University, Yulin, Shanxi, 719000, P.R. China \\ 932864974@qq.com
}

Keywords: Academic competition; Organization system; Training model; Applied talent

\begin{abstract}
Considering shortcomings of existing applied talent training method of China's universities based on academic competition, an academic competition organization and management system is established in this paper from the management organization, information exchange channels, competition management system and student incentive system. Training, course, laboratory, study club, teaching and research office and project are integrated organically with academic competition, forming a new talent training mode based on academic competition. It can provide universities some assistance in applied talent training.
\end{abstract}

\section{Introduction}

Higher education is to train senior professional talents with innovation spirit and practical ability. Innovation spirit and practical ability are essential means and important contents for universities to train applied talents in adapt to time requirements [1,2,3]. Applied talent refers to skilled talents who can use mature technologies and theories in practical production and life. They shall possess certain practical ability and strong innovation ability. At present, academic competition flourishes increasingly in universities, which is the premise to offer the society more qualified applied talents [4, $5,6]$.

Academic competition is an extracurricular scientific and technological activity to university students. It can train students' operational ability and innovation, stimulate their potentials and creativity, improve their psychological quality and team work spirit and enhance ability to solve practical problems $[7,8]$. With the continuous deepening of education reform recently, universities in China attach high attentions to academic competition and have made beneficial explorations on training of students' innovation ability and practical ability, but only achieved results of varying quality. Therefore, it is urgent to study the training model and provide solutions to applied talent training of universities $[9,10]$.

\section{Perfect the Organization System of Academic Competition}

To train good applied talents based on academic competition, the academic competition shall be organized, right and purposeful from the system.

Management Organization. Perfect organization and sound operation mechanism are important guarantees of scientific academic competition activities.

Universities and colleges shall establish a multilevel management organization to protect effective execution of project; establish a "Competition Committee" (CC) which is composed of college leaders (director) and managers of different teaching and research offices, laboratory and the competition to be responsible for organization, coordination and planning of scientific innovation activities to students, increasing roles of student competition in the university management as well as creating good preconditions for long-term effective implementation of academic competitions.

Increase propaganda through various ways and forms (e.g. microblog, WeChat, university newspaper, theme class meeting, mobilization and commendation meeting of academic competition) to increase publicity of academic competitions among students; create a positive, health and 
innovative cultural and academic atmosphere; and stimulate initiatives and enthusiasm of students in academic competition.

Information Exchange Channels. Lack of information channel is the most prominent problem against long-term effective competition development.

Related academic competition information is released in a specific scope and is accessed by some teachers through their ways, resulting in the small involved range and low popularity and participation rate of academic competitions.

Universities shall establish a competition information team to collect information timely and construct smooth information transmission channels. The competition information team is responsible for collecting and releasing academic competition information and transmitting it to CC in time through specific channel. After the competition information is confirmed, the competition director shall implement follow-up affairs under the supervision of CC director, ensuring smoothness of academic competition information transmission.

Competition Management System. For good organization of academic competitions it is necessary to have a complete management system and establish a long-term effective management system.

For the moment, universities of all levels and types are establishing academic competition management systems positively. High-efficiency competition management requires a perfect organization structure and a perfect management system. Scientific, standard and institutional management and implementation rules for university students to participate in a variety of scientific and cultural competition activities and academic competition activities are formulated according to the school files, practical situations and experiences of other schools, which give institutional guarantees for continuous holding of academic competitions.

Student Incentive System. Positive participation of students is key to the success of academic competition activities.

Academic competition without participation of students just like "water without a source". An optimized incentive system and scientific management can arise enthusiasm of students, encourage students to study discipline knowledge and participate in training and design, as well as improve students' innovation ability and performance. Based on basic incentive system of universities, the following incentives can stimulate students' passion to participate in academic competitions.

(1) Provincial or higher academic competition can serve as some internship and win certain credits;

(2) Students with good performances in academic competitions shall be appraised and rewarded priori to other students under same conditions;

(3) Offer a certain amount of student subsidies to support poor students to participate in academic competition;

(4) Others.

\section{Perfect the Organization System of Academic Competition}

Combination of Competition and Training. Universities can train students through competitions and accomplish competitions through training.

One competition will run through the college life of participated students. Each academic competition is implemented by the competition director, which is equal to tutor responsibility system. In the real tutor responsibility system, tutor is the direct guider of students from talent selection, task planning, competition performance and follow-up training.

Tutor assesses and selects talents. Hard working is the most important assessment index. This is because the future competition program requires tremendous time and efforts of students.

Next, selected students shall be trained to integrate with the competition. Early training is extremely necessary for challenging competition activities, so that students will have a general understanding on basic knowledge and methods of the competition activity. For unfinished program, students shall be selected and eliminated according to practical situations. 
After the early training, students are divided into several teams to be responsible for specific competitive activities. Assign stage tasks to students of each competition according to practical situations. At least three simulations shall be implemented before the competition to correct errors and achieve good performance.

After the second term of junior, students will make decision between further education and job hunting. The tutor will ask students who want to take part in the postgraduate entrance exam to leave the experiment and prepare for the exam completely.

After the second term of senior, students who have admitted by the postgraduate program are mainly responsible for paper writing and patent application which are derived from competitions. This not only allows students to make contributions to the university, but also trains their ability of paper writing and patent application. Students who have entered the career life are mainly responsible for training of low-grade students and guidance of competition activities.

Combination of Competition and Course. Promote reforms of course content and teaching method through competitions.

Combining course reform and competition contents closely has very important practical significance to the educational reform development. To improve course teaching and method, key attentions shall be paid to teaching of basic knowledge about academic competition in both theoretical and experimental teaching programs. "Teaching-related discipline knowledge-competition participation" shall be combined organically. In this way, the teaching program will have an explicit goal, stimulate students' learning enthusiasm, improve students' professional skills and consciousness of competition, and train students' ability of practical application. In experimental teaching, course content shall be combined with academic competition as much as possible to train operational ability of students.

Combination of Competition and Laboratory. The laboratory is used as the competition training and learning place and the competition is accomplished under the assistance of open laboratory programs.

Academic competition has outstanding feature of practice, whereas laboratory construction and opening are important support to academic competition activities to university students. According to needs of academic competition, software and hardware related with competition shall be purchased firstly during laboratory construction, which can provide strong support for students to take part in academic competitions. A laboratory management system shall be established and a special person shall be assigned responsible for open management of the laboratory, thus giving students adequate time and good conditions for training.

Due to heavy course burdens, students can only participate in training and competition in spare time. Therefore, it is difficult to meet needs of academic competition if the laboratory opens according to normal teaching time.

Combination of Competition and Study Club. Special study clubs shall be established, which is convenient for propaganda and communication of students.

Based on study clubs, students can learn from others' strong points to offset his/her weakness, receive directional guidance from teachers, learn from competition in spare time, and give full play to their outstanding professional skills in competitions.

Meanwhile, several innovation teams and scientific teams shall be built in the study club to be responsible for different parts of the competition program. This mode is characteristic of students-oriented and high dependence on study club, laboratory and academic competition activities. It allows students to feel and learn in specific design practices, materialize theoretical learning, and solve practical problems through team work.

Combination of Competition and Teaching and Research Offices. Innovative talent training won't succeed without an innovative teacher team.

Innovative talent training emphasizes on individual development of students, which is difficult to be achieved by classroom teaching which only obeys to teaching plan and concentrates on general training. As a result, it is necessary to expand extracurricular learning or the second classroom from 
the limited classroom time. The combination of competition and teaching and research offices offers academic competition a teacher team with high comprehensive quality and strong business abilities. More teachers with high theoretical level and rich practical experiences are needed to ensure quantity and quality of the teacher team.

Besides, the teaching and research offices and teachers can expand their development ideas and become aware of shortages in knowledge accumulation and practical ability by guiding competition activities, thus encouraging teachers to improve business level and abilities invisibly. It also can drive them to think about all teaching programs comprehensively, adjust the teaching contents to adapt to competition requirements, and give better guidance to students.

Combination of Competition and Programs. To accomplish academic competition better, competition programs shall be approved to promote and supervise the competition activity.

Academic competitions generally reflect the leading knowledge of the discipline. Hence, approval of derived topics of academic competition can urge students to accomplish the program and provide certain financial support to students. Students can study the approved program carefully and use related topics of the academic competition as the graduation project.

Most students participated in academic competition finish their graduation projects in the first term of junior. Moreover, combined study of competition and research project will attract more interests of teachers.

\section{Summary}

Organizing students to participate in various scientific innovative activities and making scientific researches and innovative entrepreneurship practice positively based on academic competitions play an important role in promoting students' all-round development, improving comprehensive quality and training applied talents.

This paper introduces applied training talents of China's universities from organization system of academic competition and training mode based on academic competition.

This paper still has some shortages. Future researches can explore following contents and strengthen the training mode.

(1) Establish credit system for academic competition to replace credit system of optional courses.

(2) Increase incentive system to teachers and arouse teachers' enthusiasm.

(3) Change experimental contents and assessment method, and train operational ability of students.

\section{Acknowledgements}

This work was financially supported by the university-industry cooperation projects of Yulin science and technology Bureau (2014cxy-08-02).

\section{References}

[1] F. Giuliano: Archives of Environmental and Occupational Health, Vol. 68 (2013) No.2, p.123-7.

[2] D.O. Elias, C.A. Botero, M. Andrade, A.C. Mason and M.M. Kasumovic: Behavioral Ecology, Vol. 21 (2010) No.4, p.868-875.

[3] T.A. Branch, J.D. Austin, K.Acevedo. Whitehouse, I.J. Gordon, M.E. Gompper, T.E. Katzner and N. Pettorelli: Animal Conservation, Vol. 15 (2012) No.1, p.1-3.

[4] A.M. Sarhan, D.C. Hamilton and B. Smith: Reliability Engineering \& System Safety, Vol. 95 (2010) No.9, p.953-962.

[5] T. Long, X.T. He: Modern Physics Letters B, Vol. 12 (1998) No.22, p.943-954.

[6] E. Huchard, G. Cowlishaw: Behavioral Ecology, Vol. 22 (2011) No.5, p.1003-1011. 
[7] P. Marks: New Scientist, Vol. 207 (2010) No.2779, p.26.

[8] K. Kim, T.S. Tse: ision Support Systems, , Vol. 52 (2011) No.2, p.427-437.

[9] Y.C. Chai, T. Papathomas, X. Zhuang, D. Alais:Journal of Vision, Vol. 9 (2010) No.8, p.303.

[10] G. Franco: chives of Environmental \& Occupational Health, Vol.68 (2013) No.2, p.123-127. 